Universidade do Rio Grande do Sul

\title{
Revista da Faculdade de Direito de
} PôRTO ALEGRE

Anais do Congresso Jurídico Comemorativo do Cinqüentenário da Faculdade

Vol. II

1951 
REVISTA

DA

FACULDADE DE DRRETO

ID

PôRTO ALEGRE 


\section{Prof. Alexandre Martins da Rosa}

Diretor da Faculdade de Direito

\section{Prof. José Salgado Martins}

Armando Pereira da Câmara - Catedrático - Introdução à Ciência do Direito ( $1 . .^{\circ}$ ano). - Filosofia do Direito $\left(5 .^{\circ}\right.$ ano).

Darcy Pereira de Azambuja - Catedrático - Teoria Geral do Estado (1. ${ }^{\circ}$ ano) Direito Constitucional $\left(2 .^{\circ}\right.$ ano)

Mem de Sá - Cotedrático - Economia Política $\left(1 .^{\circ}\right.$ ano $)$

Elpídio Ferreira Paes - Catedrático - Direito Romano $\left(1 .^{\circ}\right.$ ano

Edgar Luiz Schneider - Catedrático - Ciência das Finonças $\left(20^{\circ}\right.$ ano).

José Salgado Martins - Catedrático - Direito Penal $\left(2 .^{\circ}\right.$ ano e $3 .^{\circ}$ ano)

Oswaldo Caminha - Catedrático - Direito Civil (2. ano e $3 .^{\circ}$ ano).

Amadeu Fagundes de Oliveira Freitas - Catedrático - Direito Público Internacional $\left(3 .^{\circ}\right.$ ano)

Herneni Estrella - Catedrático - Direito Comercial $\left(3 .^{\circ}\right.$ ano e $4 .^{\circ}$ ano)

Armando Dias de Axevedo - Catedrático - Direito Civil $\left(4 .^{\circ}\right.$ ano e $5 .^{\circ}$ ano)

Corlos Pitta Pinheiro - Catedrático - Medicina Legal (4. ${ }^{\circ}$ ano).

Celso Cezer Papaleo - Livre-Docente - Medicina Legal (4..$^{\circ}$ ano).

Dario de Bittencourt - Livre-Docente - Direito Industrial e Legislaçáo do Trabalho (4. ${ }^{\circ}$ ano).

Eloy José da Rocha - Catedrático - Direito Industrial e Legislação do Trabalho $\left(4 .^{\circ}\right.$ ano).

Vicente Marques Santiago - Catedrático - Direito Judiciário Civil $\left(40^{\circ} \mathrm{C}\right.$ $5 .^{\circ}$ ano).

Franeisco José Simch Junior - Catedrático - Direito Judiciário Penal $\left(50^{\circ}\right.$ ano).

Joáo Bonumá - Catedrático - Direito Judiciário Civil $\left(4 .^{\circ}\right.$ e $5 .^{\circ}$ ano).

Ney da Silva Wiedemann - Catedrático - Direito Internacional Privado $\left(5 .^{\circ}\right.$ ano).

Ruy Cirne Lima - Catedrático - Direito Administrativo e Ciência da Administração $\left(50^{\circ}\right.$ ano $)$.

Secretário da Foculdade - Dr. Euclydes Henriques de Castro

\section{Revista da Faculdade de Direito de}

\section{PÔRTO ALEGRE}

Anais do

Congresso Jurídico

Comemorativo do Cinqüentenário da Faculdade

\section{Vol. II}

1951 